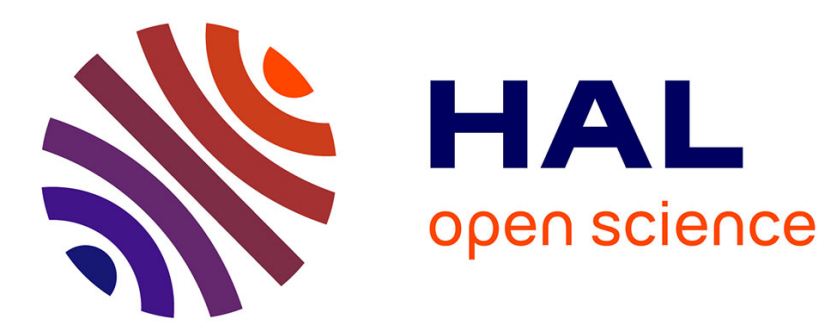

\title{
Records of bottlenose dolphins, Tursiops spp., in New Caledonian waters
}

Philippe Borsa, Serge Andréfouët, Matthieu Juncker

\section{To cite this version:}

Philippe Borsa, Serge Andréfouët, Matthieu Juncker. Records of bottlenose dolphins, Tursiops spp., in New Caledonian waters. Marine Biodiversity Records, 2012, 5, pp.e53. ird-00708068v2

\section{HAL Id: ird-00708068 https://hal.ird.fr/ird-00708068v2}

Submitted on 15 Oct 2012

HAL is a multi-disciplinary open access archive for the deposit and dissemination of scientific research documents, whether they are published or not. The documents may come from teaching and research institutions in France or abroad, or from public or private research centers.
L'archive ouverte pluridisciplinaire HAL, est destinée au dépôt et à la diffusion de documents scientifiques de niveau recherche, publiés ou non, émanant des établissements d'enseignement et de recherche français ou étrangers, des laboratoires publics ou privés. 
To be cited as:

Borsa P., Andréfouët S., Juncker M. 2012. - Records of bottlenose dolphins, Tursiops spp., in New Caledonian waters. Marine Biodiversity Records 5, e53.

\section{Records of bottlenose dolphins, Tursiops spp., in New Caledonian waters}

\section{PHILIPPE BORSA ${ }^{1}$, SERGE ANDREFOUËT ${ }^{2}$ AND MATTHIEU JUNCKER ${ }^{3}$}

${ }^{1}$ Institut de recherche pour le développement, UR 227 'Biocomplexité des écosystèmes récifaux', Centre IRD de Montpellier, Montpellier, France, ${ }^{2}$ Institut de recherche pour le développement, UR 227 'Biocomplexité des écosystèmes récifaux', Centre IRD de Nouméa, Nouméa, New Caledonia, ${ }^{3}$ Observatoire de l'environnement en Nouvelle-Calédonie, Nouméa, New Caledonia

Correspondence should be addressed to:

P. Borsa

Institut de recherche pour le développement

UR 227 'Biocomplexité des écosystèmes récifaux'

Centre IRD de Montpellier-PS2, 911 avenue Agropolis, 34032 Montpellier cx, France

email: philippe.borsa@ird.fr 
Observations of bottlenose dolphins, Tursiops spp. were made opportunistically between 1993 and 2009 in New Caledonian waters (eastern Coral Sea, southwestern Pacific). Two morphotypes, defined from pigmentation patterns, were observed: morphotype-B individuals possessed a distinctive, extensive pale-grey blaze that indents the darker-grey dorsal cape towards the basis of the dorsal fin while morphotype-A individuals lacked it. Morphotype-A bottlenose dolphins occurred in pods of 2-10 individuals whereas pods of morphotype-B bottlenose dolphins comprised up to $\sim 30$ individuals. All morphotype-A bottlenose dolphin sightings were made in inshore waters, and all morphotype-B bottlenose dolphin sightings were made offshore. Wounds inflicted by large sharks, including the tiger shark, were documented for morphotype-A bottlenose dolphins. Leisure-boat traffic is likely to be the cause of additional injuries to bottlenose dolphins in the New Caledonian lagoon. Pigmentation patterns and correlated habitat preferences of morphotype-A and $\mathrm{B}$ bottlenose dolphins were consistent with those of, respectively, T. aduncus and T. truncatus in the western Coral Sea and elsewhere in the Pacific Ocean.

Keywords: Coral Sea, New Caledonia, Indo-Pacific, pigmentation patterns, habitat segregation, Tursiops aduncus, Tursiops truncatus

\section{INTRODUCTION}

The diversity and distribution of marine mammals around oceanic islands in Oceania including, in particular, the New Caledonian archipelago, remain poorly known (Reeves et al. 1999; Wells and Scott 2002; Wang and Yang 2009). This is true, in particular, for bottlenose dolphins (Tursiops spp.) (Wang and Yang 2009). Bottlenose dolphins have a world-wide distribution, and show morphotypic variation among regions (Rice 1998; Hoelzel et al. 1998; Wells and Scottt 2002). Distinctions between coastal and pelagic populations have been documented worldwide.

Two main morphological types of bottlenose dolphins based on tooth count and cranial morphology (Perrin et al. 2007), referred to as distinct nominal species, are currently considered: $T$. truncatus (Montagu 1821) (the common bottlenose dolphin) and T. aduncus (Ehrenberg 1833) (the IndoPacific bottlenose dolphin) (Rice 1998). Useful characters for distinguishing T. aduncus from T. truncatus by external appearance are rostrum length, ratios of rostrum length to body length and to snout-to-eye length, body size, and pigmentation patterns (Hale et al. 2000; Wang et al. 2000; Wang and Yang 2009). T. aduncus and T. truncatus co-occur in the tropical Indo-Pacific, where habitat segregation has been documented, T. aduncus occupying inshore waters and T. truncatus tending to occur offshore (Ross 1977; Gao et al., 1995; Hale et al. 2000; Möller and Beheregaray 2001; Wells and Scott 2002; Wang and Yang 2009). However, currently there is not enough evidence to know whether the different ecotypes or ecomorphs of bottlenose dolphin are consistently the same species in all parts of the Indo-Pacific where they are recorded (Wang and Yang 2009). Pending further osteological and genetic evidence, it is wise to provisionally refer to the generic name 'Tursiops spp.' in presently poorly surveyed regions of the world, such as New Caledonia.

Partly based on stranded specimens, both $T$. aduncus and T. truncatus bottlenose dolphins have been mentioned in a list of marine mammals from New Caledonia (Borsa 2006), but information on their relative abundance, group size, period of occurrence, and habitat segregation in New Caledonian waters are still lacking. The aim of the present report is to contribute to filling that gap by summarizing and discussing recent sightings of bottlenose dolphins from New Caledonian waters.

\section{MATERIALS AND METHODS}


'New Caledonian waters' is here defined as the area adjacent to the island of New Caledonia, eastern Coral Sea (Southwest Pacific), extending seaward from the mean low water mark to the boundary of the exclusive economic zone. Opportunistic sightings of bottlenose dolphins, Tursiops spp. in New Caledonian waters were recorded from mid-1994 to mid-1995 and from 2002 to mid-2009. Observations were made either from research vessels, diving boats, or sailboats, or from the shore. Position, pod size, the eventual presence of newborns, and behaviour were systematically recorded. Pigmentation patterns were noted when visual conditions were favourable. During the same period, additional observations were obtained by P.B. from fellow scuba divers and naturalists. Depth was obtained from echosounders, or a posteriori from nautical charts.

Here, two morphotypes of bottlenose dolphin, coined $A$ and $B$, could be distinguished at sea from the pigmentation patterns of their back (Fig. 1A-D). Morphotype- $B$ individuals exhibited a distinctive, extensive pale-grey blaze that indents the darker-grey dorsal cape towards the basis of the dorsal fin (Fig. 1C) and which was absent or unconspicuous in morphotype- $A$ bottlenose dolphins (Fig. $1 \mathrm{~A}, \mathrm{D})$. The body build of morphotype- $B$ bottlenose dolphins also appeared stockier than that of morphotype- $A$ bottlenose dolphins (Fig. 1A, B).

Many of the observations of Tursiops spp. that have been compiled by us, mainly from the southwestern lagoon of New Caledonia, lacked sufficiently precise information on pigmentation patterns and therefore were not included in the present report. Also excluded were two strandings of Tursiops sp. reported by Borsa (2006) and a sighting of a single individual Tursiops sp. in the Chesterfield lagoon (1953’S 158²7’E; Borsa 2008).

\section{RESULTS}

Table 1 reports all observations of Tursiops spp. where the morphotype $(A$ or $B)$ of the individuals sighted could be determined, during the survey period. Four observations from the literature were also included, including two skulls of individuals stranded on Isle of Pines in 1977 and 1980, and identified to species (as T. aduncus) by D. Robineau (pers. comm.). The distribution of sightings is summarized in Fig. 2. All sightings of morphotype- $A$ bottlenose dolphins (22 sightings, totalling $\geq 87$ individuals) occurred inshore around New Caledonia's main island, within the lagoon delimitated by the barrier reef, and at depths less than $\sim 40 \mathrm{~m}$. All sightings of morphotype- $B$ bottlenose dolphins ( 4 sightings, totalling $\sim 36$ individuals), as well as that of a live-biopsied T. truncatus (Table 1), were made off the barrier reef, at depths $>40 \mathrm{~m}$. There is no barrier reef in Baie des Tortues, where morphotype- $B$ individuals were sighted closest to shore (Table 1; Fig. 2). Morphotype- $A$ bottlenose dolphins occurred in small groups, from 2 to 10 individuals, whereas morphotype- $B$ bottlenose dolphins occurred in groups of two up to $\sim 30$ individuals.

A proportion of morphotype- $A$ individuals wore scars attributable to large sharks (Fig. $1 \mathrm{~A}, \mathrm{D}$ ). Other morphotype- $A$ individuals had a damaged dorsal fin, seemingly a consequence of strikes from boat propellers: in one individual, the dorsal fin was separated in two by a deep and straight vertical gash in its middle (22 $18^{\prime} \mathrm{S} 166^{\circ} 26^{\prime} \mathrm{E}$; Aug. 2002 ) and in another individual, the dorsal fin was obliquely cut clean through $\left(21^{\circ} 57^{\prime} \mathrm{S} 166^{\circ} 02^{\prime} \mathrm{E}\right.$; Aug. 2007).

We observed small pods of morphotype- $A$ individuals chasing torpedo scads, Megalaspis cordyla

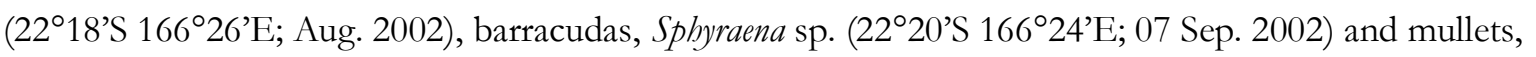
Mugilidae sp. (22 $18^{\circ} \mathrm{S} 166^{\circ} 26^{\prime} \mathrm{E}$; May 2002) in shallow water close to shore. We also observed a pod of morphotype- $A$ individuals foraging for more than two hours at night in very shallow water $(<3 \mathrm{~m})$ under 
the spotlights of a built-on-piles restaurant at Anse Vata, Nouméa (Nov. 2006). The spotlights were turned towards the sea, to attract fishes and squids and entertain the customers. The same behaviour was observed by P.B. on two consecutive nights in the harbour of Sorong (West Papua) in July 2010, where a pod of three morphotype- $A$ bottlenose dolphins was preying on squids and fishes attracted by the lights of an anchored vessel. Morphotype- $B$ bottlenose dolphins were observed chasing flying fishes, Exocoetidae sp., in the open sea (22 $35^{\prime} \mathrm{S} 166^{\circ} 28^{\prime} \mathrm{E}$; Feb. 2002).

\section{DISCUSSION}

The similarities in pigmentation patterns and habitat characteristics of morphotype- $A$ and morphotype- $B$ bottlenose dolphins from New Caledonia (present report), and, respectively, T. aduncus and T. truncatus from southern Queensland (Hale et al. 2000) and from elsewhere in the Indo-Pacific (Wang and Yang 2009) are strong enough to suggest that morphotype $A$ corresponds to T. aduncus under its current definition (Rice 1998) and morphotype $B$, to T. truncatus. However, pending more genetic evidence, in the following we will refer to "T. aduncus-like" and "T. truncatus-like" bottlenose dolphins in New Caledonian waters. Also, adult T. aduncus generally exhibit dark spots on the posterior ventral half of the body (Hale et al. 2000), but T. aduncus populations from New South Wales and southeastern Australia are "apparently more or less unspotted" (Ross and Cockroft 1990; Wang and Yang 2009). When present, only light spotting on the posterior part of the body was noticed by us on some New Caledonian morphotype- $A$ individuals (Fig. 1D). The presence or absence of a pale-grey blaze below the dorsal fin remained the easiest way to distinguish between the two forms in the field.

The present results thus confirm that both T. aduncus-like and T. truncatus-like bottlenose dolphins are present in New Caledonian waters, where they seem to occur year-round, thereby providing new details on their distribution in the southwestern tropical Pacific relative to previous work (Reeves et al. 1999; Borsa 2006; Wang and Yang 2009). T. aduncus-like bottlenose dolphins apparently mainly, if not exclusively occur inside the coral-reef lagoon that surrounds New Caledonia's Grande Terre whereas $T$. truncatus like individuals have so far been sighted exclusively off the barrier reef.

Although the density of the human population in New Caledonia is low (ca. 245,000 inhabitants for a territory totalling ca. $19,000 \mathrm{~km}^{2}$ ), the coral-reef lagoon of New Caledonia is under serious threat of degradation from the deforestation, land erosion and pollution caused by developing open-pit mining projects and associated ore-processing plants (Richer de Forges and Pascal 2008). Overfishing has been reported for some areas of the New Caledonian lagoon and further fishing pressure on fish stocks is expected in relation with the industrial development of once sparsely populated littoral regions (Guillemot et al. 2009). Both habitat degradation and overfishing may affect the availability of fish prey to T. aduncuslike bottlenose dolphins in at least some areas of the New Caledonian lagoon. Another threat to $T$. aduncus-like bottlenose dolphin populations in New Caledonia is the increased disturbance and risk of boat strike related to the rapidly increasing leisure-boat traffic: approximately 25,000 leisure boats, many of them being motorized speedboats, are currently registered in New Caledonia. That number is steadily increasing by ca. 1,000 new boats every year (Service de la marine marchande et des pêches maritimes, Nouméa, pers. comm.). Collision with boats or ships has been documented for several marine mammal species in New Caledonian waters: these include the dwarf and pygmy sperm whales, the humpback whale and, mostly, the dugong (Borsa 2006). The characteristics of some of the wounds exhibited by T. aduncuslike bottlenose dolphins suggest they resulted from boat propeller strikes. Monitoring the abundance and 
distribution of T. aduncus-like bottlenose dolphins should be considered in assessing the ecological impact of developing human activities in the New Caledonian lagoon.

\section{ACKNOWLEDGEMENTS}

We are grateful to D. Robineau (Museum national d'histoire naturelle, Paris) for excellent information and to C.D. MacLeod for helpful suggestions.

\section{REFERENCES}

Borsa P. (2006) Marine mammal strandings in the New Caledonia region, southwest Pacific. Comptes Rendus Biologies 329, 277-288.

Borsa P. (2008) Mission ornithologique à l'îlot Loop (îles Chesterfield) et transects en mer de Corail et dans le bassin des Loyauté, 20-28 octobre 2008. IRD, Nouméa, 13 pp. (available from http://hal.archives-ouvertes.fr/).

Ehrenberg C.G. (1833) Mammalia, decade II. In Hemprich F.W. and Ehrenberg C.G. Symbolae physicae, seu icons et descriptions corporum naturalium novorum aut minus cogitorum, quae ex itineribus per Libyam, Aegyptum, Nubiam, Dongalam, Syriam, Arabiam et Habessiniam publico institutis sumptu Friderici Guilelmi Hemprich et Cristiani Godofredi Ehrenberg studio annis MDCCCXX-MDCCCXXV redierunt. Pars Zoologica. Officina academica, Berolini.

Gao A., Zhou K. and Wang Y. (1995) Geographical variation in morphology of bottlenose dolphins (Tursiops sp.) in Chinese waters. Aquatic Mammals 21, 121-135.

Guillemot N., Léopold M., Cuif M. and Chabanet P. (2009) Characterization and management of informal fisheries confronted with socio-economic changes in New Caledonia (South Pacific). Fisheries Research 98, 51-61.

Hale P.T., Barreto A.S. and Ross G.J.B. (2000) Comparative morphology and distribution of the aduncus and truncatus forms of bottlenose dolphin Tursiops in the Indian and Western Pacific Oceans. Aquatic Mammals 26, 101-110.

Hoelzel A.R., Potter C.W. and Best P.B. (1998) Genetic differentiation between parapatric 'nearshore' and 'offshore' populations of the bottlenose dolphin. Proceedings of the Royal Society B: Biological Sciences 265, 1177-1183.

Möller L.M. and Beheregaray L.B. (2001) Coastal bottlenose dolphins from southeastern Australia are Tursiops aduncus according to sequences of the mitochondrial DNA control region. Marine Mammal Science 17, 249-263.

Montagu G. (1821) Description of a species of Delphinus that appears to be new. Memoirs of the Wernerian Natural History Society 3, 75-82.

Perrin W.F., Robertson K.M., van Bree P.J.H. and Mead J.G. (2007) Cranial description and genetic identity of the holotype specimen of Tursiops aduncus (Ehrenberg, 1832). Marine Mammal Science 23, 343-357.

Reeves R.R. and Brownell R.L.Jr. (Eds.) (2009) Report of the assessment workshop on Indo-Pacific bottlenose dolphins (Tursiops aduncus) with the Solomon Islands as a case study. Cetacean Specialist Group, Species Survival Commission, IUCN. Gland: IUCN,. 65 p. 
Reeves R.R., Leatherwood S., Stone G.S. and Eldredge L.G. (1999) Marine mammals in the area served by the South Pacific Regional Environment Programme (SPREP). Apia: SPREP, viii+48 p.

Rice D.W. (1998) Marine mammals of the world, systematics and distribution. Society for Marine Mammalogy Special Publication 4. Lawrence: Allen Press, 231 p.

Richer de Forges B. and Pascal M. (2008) La Nouvelle-Calédonie, un «point chaud » de la biodiversité mondiale gravement menacé par l'exploitation minière. Journal de la Société des Océanistes 126-127, 95111.

Ross G.J.B. (1977) The taxonomy of the bottlenose dolphins Tursiops species in South African waters, with notes on their biology. Annals of the Cape Provincial Museums (Natural History) 11, 135-194.

Ross G.J.B. and Cockcroft V.G. (1990) Comments on Australian bottlenose dolphins and taxonomic status of Tursiops aduncus (Ehrenberg, 1832) . In Leatherwood S. and Reeves R.R. (eds.) The bottlenose dolphin. San Diego: Academic Press, pp. 101-128.

Ryan W.B.F., Carbotte S.M., Coplan J.O., O’Hara S., Melkonian A., Arko R., Weissel R.A., Ferrini V., Goodwillie A., Nitsche F., Bonczkowski J. and Zemsky R. (2009) Global multiresolution topography synthesis. Geochemistry Geophysics Geosystems 10, Q03014.

Tezanos-Pinto G., Baker C.S., Russell K., Martien K., Baird R.W., Hutt A., Stone G., MignucciGiannoni A.A., Caballero S., Endo T., Lavery S., Oremus M., Olavarria C. and Garrigue C. (2009) A worldwide perspective on the population structure and genetic diversity of bottlenose dolphins (Tursiops truncatus) in New Zealand. Journal of Heredity 100, 11-24.

Wang J.Y., Chou L-S. and White B.N. (2000) Differences in the external morphology of two sympatric species of bottlenose dolphins (genus Tursiops) in the waters of China. Journal of Mammalogy 81, 11571165.

Wang J.Y. and Yang S.C. (2009) Indo-Pacific bottlenose dolphin Tursiops aduncus. In Perrin W.F., Würsig B. and Thewissen J.G.M. (eds.) Encyclopedia of marine mammals, $2^{\text {nd }}$ edn. Amsterdam: Academic Press, pp. 602-608.

and

Wells R.S. and Scott M.D. (2002) Bottlenose dolphins. In Perrin W.F., Würsig B. and Thewissen J.G.M. (eds.) Encyclopedia of marine mammals. San Diego: Academic Press, pp. 122-128. 
Table 1. Opportunistic sightings of bottlenose dolphin, Tursiops spp., by morphotype ( $A$ and $B$ ), and additional strandings and observation of T. aduncus and T. truncatus, in New Caledonian waters. Depth was obtained from echosounder, or a posteriori from nautical charts. $N$, pod size (except for numbers in brackets)

\begin{tabular}{|c|c|c|c|c|c|}
\hline Site & Coordinates & Depth & Date & $N$ & Observer \\
\hline \multicolumn{6}{|l|}{ Morphotype $A$} \\
\hline $\mathrm{N}$ of Tibarama Islet & $20^{\circ} 54^{\prime} \mathrm{S} 165^{\circ} 22^{\prime} \mathrm{E}$ & $\sim 15 \mathrm{~m}$ & 13 Jan. 2002 & $7-10$ & M. Ravannah \\
\hline Off Poindimié & $20^{\circ} 54^{\prime} \mathrm{S} 165^{\circ} 25^{\prime} \mathrm{E}$ & $\sim 40 \mathrm{~m}$ & 14 Jan. 2002 & $7-10$ & G. Hoarau \\
\hline Nepoui Bay & $21^{\circ} 22^{\prime} \mathrm{S} 164^{\circ} 28^{\prime} \mathrm{E}$ & $9 \mathrm{~m}$ & 26 Sep. 2004 & 3 & P.B. \\
\hline Off Kouaoua & $\sim 21^{\circ} \mathrm{S} \sim 166^{\circ} 5 \mathrm{E}$ & - & - & $\geq 6$ & C. Garrigue (Reeves and Brownell 2009) \\
\hline Ouanno wharf & $21^{\circ} 46^{\prime} \mathrm{S} 165^{\circ} 45^{\prime} \mathrm{E}$ & $2 \mathrm{~m}$ & 04 Sep. 2005 & 4 & P.B., Rumini \\
\hline Ouanno Bay & $21^{\circ} 47^{\prime} \mathrm{S} 165^{\circ} 43^{\prime} \mathrm{E}$ & $7 \mathrm{~m}$ & 03 Sep. 2005 & 2 & P.B. \\
\hline NW of Puen Island & $21^{\circ} 57^{\prime} \mathrm{S} 165^{\circ} 56^{\prime} \mathrm{E}$ & $8 \mathrm{~m}$ & 26 June 1994 & $5-6$ & J.-C. Vernus \\
\hline Puen Island & $21^{\circ} 57^{\prime} \mathrm{S} 165^{\circ} 58^{\prime} \mathrm{E}$ & $6 \mathrm{~m}$ & 08 Jan. 2002 & 3 & P.B. \\
\hline Puen Island & $21^{\circ} 57^{\prime} \mathrm{S} 165^{\circ} 58^{\prime} \mathrm{E}$ & $6 \mathrm{~m}$ & 01 Sep. 2002 & 3 & P.B. \\
\hline Bouraké & $21^{\circ} 57^{\prime} \mathrm{S} 165^{\circ} 59^{\prime} \mathrm{E}$ & $6 \mathrm{~m}$ & 09 Jan. 2002 & 4 & P.B. \\
\hline Saint Vincent Bay & $21^{\circ} 57^{\prime} \mathrm{S} 166^{\circ} 02^{\prime} \mathrm{E}$ & $6 \mathrm{~m}$ & 05 Aug. 2007 & 4 & P.B. \\
\hline S of Nou Island & $22^{\circ} 17^{\prime} \mathrm{S} 166^{\circ} 24^{\prime} \mathrm{E}$ & $15 \mathrm{~m}$ & 24 Aug. 2002 & 2 & F. Fenoglio \\
\hline Off Port Moselle & $22^{\circ} 17^{\prime} \mathrm{S} 166^{\circ} 25^{\prime} \mathrm{E}$ & $15 \mathrm{~m}$ & 27 Aug. 1994 & 2 & P.B. \\
\hline Anse Vata & $22^{\circ} 18^{\prime} \mathrm{S} 166^{\circ} 26^{\prime} \mathrm{E}$ & $6 \mathrm{~m}$ & 18 Aug. 2002 & $4-5$ & P.B. \\
\hline Anse Vata & $22^{\circ} 18^{\prime} \mathrm{S} 166^{\circ} 26^{\prime} \mathrm{E}$ & $5 \mathrm{~m}$ & 18 Sep. 2006 & 3 & C. Menkes \\
\hline Anse Vata & $22^{\circ} 18^{\prime} \mathrm{S} 166^{\circ} 26^{\prime} \mathrm{E}$ & $5 \mathrm{~m}$ & 04 Nov. 2006 & $3-4$ & P.B. \\
\hline Rocher à la Voile & $22^{\circ} 18^{\prime} \mathrm{S} 166^{\circ} 26^{\prime} \mathrm{E}$ & $5 \mathrm{~m}$ & 24 Dec. 2008 & 2 & P.B. \\
\hline Baie des Citrons & $22^{\circ} 18^{\prime} \mathrm{S} 166^{\circ} 26^{\prime} \mathrm{E}$ & $8 \mathrm{~m}$ & - May 2002 & 4 & C. Boulnois \\
\hline Baie des Citrons & $22^{\circ} 18^{\prime} \mathrm{S} 166^{\circ} 26^{\prime} \mathrm{E}$ & $10 \mathrm{~m}$ & - Oct. 2002 & $3^{a}$ & C. Boulnois \\
\hline S Maître Islet & $22^{\circ} 20^{\prime} \mathrm{S} 166^{\circ} 24^{\prime} \mathrm{E}$ & $12 \mathrm{~m}$ & 23 Mar. 2002 & $8-10$ & P.B. \\
\hline S Maître Islet & $22^{\circ} 20^{\prime} \mathrm{S} 166^{\circ} 24^{\prime} \mathrm{E}$ & $12 \mathrm{~m}$ & 07 Sep. 2002 & 2 & C. Boulnois \\
\hline E of Redika islet & $22^{\circ} 27^{\prime} \mathrm{S} 166^{\circ} 42^{\prime} \mathrm{E}$ & $22 \mathrm{~m}$ & 21 June 2008 & 3 & M.J.; Fig. 1D \\
\hline N Redika Islet & $22^{\circ} 30^{\prime} \mathrm{S} 166^{\circ} 36^{\prime} \mathrm{E}$ & $\sim 11 \mathrm{~m}$ & 15 Dec. 2008 & 3 & S.A.; Fig. 1A \\
\hline \multicolumn{6}{|l|}{ Morphotype $B$} \\
\hline Grand Passage & $18^{\circ} 47^{\prime} \mathrm{S} 163^{\circ} 16^{\prime} \mathrm{E}$ & $520 \mathrm{~m}$ & 24 Oct. 2008 & $\sim 30$ & P.B.; Fig. 1B \\
\hline Baie des Tortues & $21^{\circ} 37^{\prime} \mathrm{S} 165^{\circ} 29^{\prime} \mathrm{E}$ & $>40 \mathrm{~m}$ & - Dec. 2003 & 2 & M. Hernu \\
\hline Off Kué Reef & $22^{\circ} 35^{\prime} \mathrm{S} 166^{\circ} 28^{\prime} \mathrm{E}$ & $647 \mathrm{~m}$ & 02 Feb. 2002 & 2 & P.B. \\
\hline Cappel Bank & $26^{\circ} 40^{\prime} \mathrm{S} 159^{\circ} 24^{\prime} \mathrm{E}$ & $\sim 300 \mathrm{~m}$ & 22 May 2002 & 2 & M. Planchot \\
\hline \multicolumn{6}{|l|}{ Tursiops aduncus } \\
\hline Gadji, Isle of Pines & $22^{\circ} 32^{\prime} \mathrm{S} 167^{\circ} 25^{\prime} \mathrm{E}$ & - & --1977 & (1) & D. Robineau (Borsa 2006)b \\
\hline Isle of Pines & $\sim 22^{\circ} \mathrm{S} \sim 167^{\circ} \mathrm{E}$ & - & --1980 & (1) & D. Robineau (Borsa 2006) \\
\hline \multicolumn{6}{|l|}{ Tursiops truncatus } \\
\hline SW of Isle of Pines & $22^{\circ} 51^{\prime} \mathrm{S} 167^{\circ} 42^{\prime} \mathrm{E}$ & - & - & (1) & Tezanos-Pinto et al. (2009)c \\
\hline
\end{tabular}

\footnotetext{
a includes a newborn

b stranded specimen

$\mathrm{c}$ biopsied specimen, identified to species from $\mathrm{mtDNA}$ sequence
} 
Captions to Figures

Fig. 1. Morphological variation among Tursiops spp. individuals in the Coral Sea. A. Morphotype- $A$ bottlenose dolphin photographed in the southwestern lagoon of New Caledonia (200 m north of Redika Islet, $22^{\circ} 30^{\prime}$ S $166^{\circ} 36^{\prime} \mathrm{E}$; 15 December 2008; S.A.); we interpret the series of evenly spaced marks on the flank as scars of a superficial bite from a large shark. B. Morphotype- $B$ bottlenose dolphin (Grand Passage, $18^{\circ} 47^{\prime} \mathrm{S} 163^{\circ} 16^{\prime} \mathrm{E} ; 24$ October 2008; P.B.). C. Bow-riding morphotype- $B$ bottlenose dolphins exhibiting paler-grey blaze below dorsal fin (NE of Morinda Shoals, Great Barrier Reef lagoon, $19^{\circ} 05^{\prime} \mathrm{S}$ $147^{\circ} 35^{\prime} \mathrm{E}$; 25 April 1991; P.B.). D. Posterior part of an adult morphotype- $A$ individual exhibiting sparse, tiny darker spots, and de-pigmented patterns on flank determined by us as the healed scars of a wound inflicted by a tiger shark, Galeocerdo cuvier (E of Redika Islet, 22²7’S $166^{\circ} 42^{\prime} \mathrm{E}, 21$ June 2008; M.J.).

Fig. 2. Distribution of bottlenose dolphin, Tursiops spp., sightings in New Caledonian waters.

morphotype $A ; \Delta$, T. aduncus, identified from skull morphology and tooth count; $\circ$, morphotype $B ; \bullet \bullet, T$. truncatus, identified from mitochondrial-DNA haplotype. Additional details in Table 1. Topographic map from GEOMAPAPP (http://www.geomapapp.org; Ryan et al. 2009). 

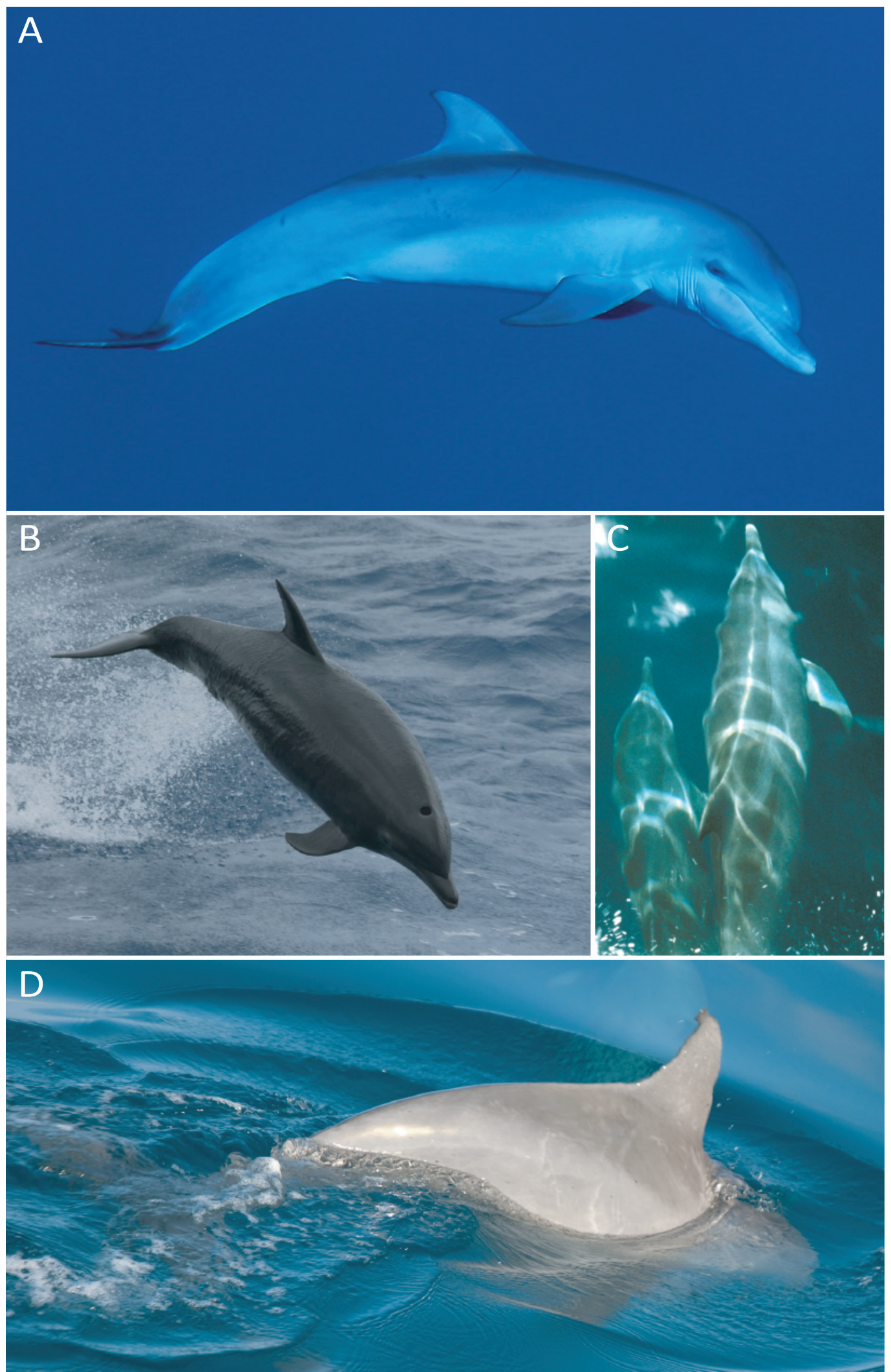


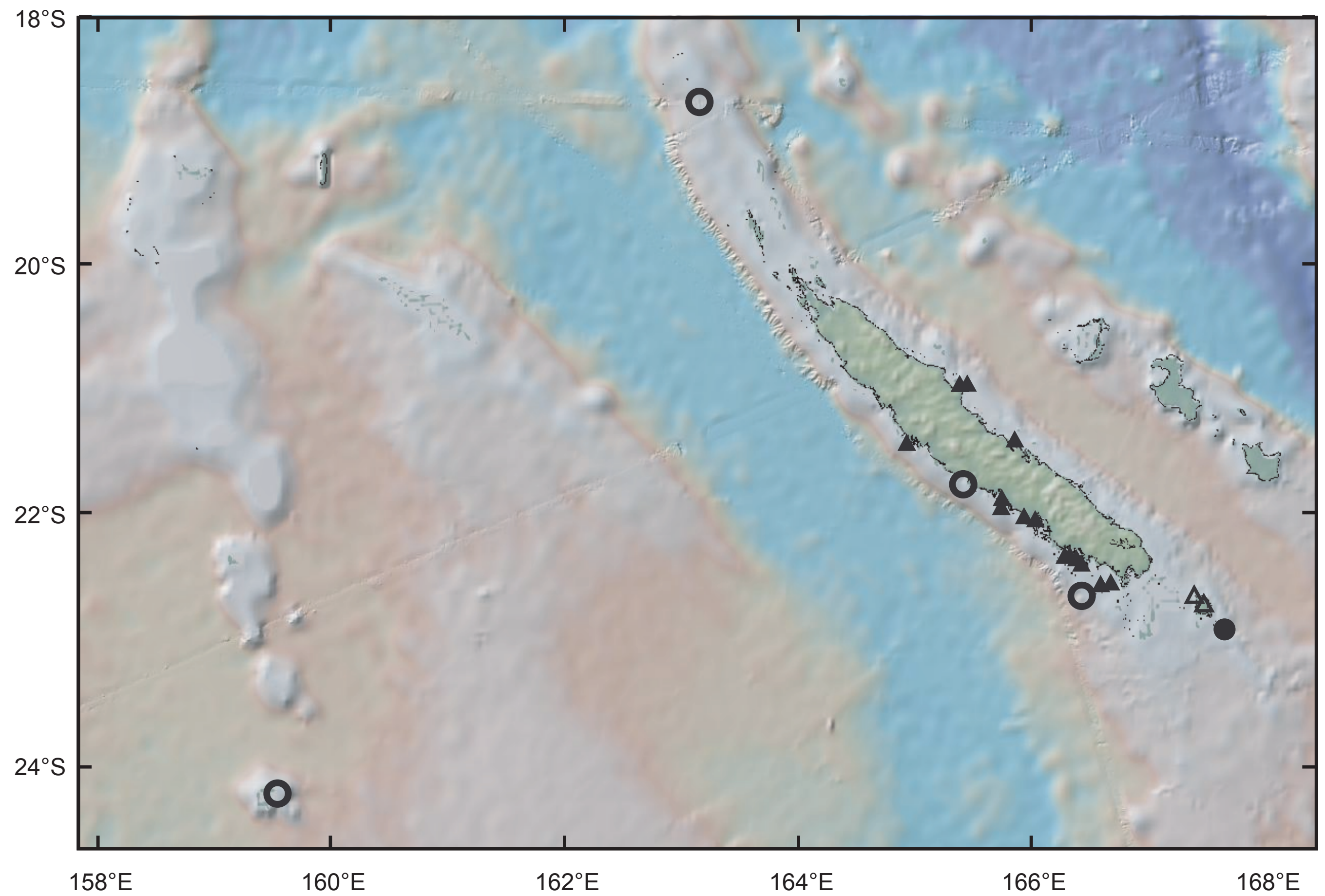

